\author{
Agata Rudnicka \\ University of Lodz \\ e-mail: rudnicka@uni.lodz.pl
}

\title{
CODES OF CONDUCT AND CODES OF ETHICS \\ AS TOOLS USED TO SUPPORT THE IDEA OF SOCIAL RESPONSIBILITY IN SUPPLY CHAINS
}

KODEKSY POSTĘPOWANIA ORAZ KODEKSY ETYCZNE JAKO NARZĘDZIA WYKORZYSTYWANE DO WSPIERANIA IDEI SPOLECZNEJ ODPOWIEDZIALNOŚCI W ŁAŃCUCHACH DOSTAW

DOI: $10.15611 /$ pn.2017.464.08

JEL Classification: M14, M19, Q56

\begin{abstract}
Summary: Suppliers are important links in the value chain of modern enterprises. The rapid changes that are happening on the market now were an impulse for the development of concepts that help to manage such a complex environment. The concept of Corporate Social Responsibility (CSR) may support the development of sustainable supply chains. The management of social issues in supply chains is becoming more and more important. The main reasons for that is the increasing risk of undesirable situations in supply chains that can cause real problems for business. One of possible responds of business is the implementation of code of conduct or code of ethics addressed to suppliers. This paper presents the potential role of codes of ethics and codes of conduct as tools that support the management of social and environmental issues of supply chain. Theoretical considerations will be supported by a qualitative analysis of codes of ethics and codes of conduct published by socially responsible companies from Poland (on the basis on IX Ranking Odpowiedzialnych Firm).
\end{abstract}

Keywords: code of conduct, code of ethics, social responsibility in supply chain, qualitative analysis.

Streszczenie: Dostawcy to istotne ogniwo w łańcuchu wartości współczesnych przedsiębiorstw. Gwałtowne zmiany na rynku były impulsem do rozwoju koncepcji, które pomagają zarządzać złożonym otoczeniem. Jedną z nich jest społeczna odpowiedzialność biznesu. Ważnym elementem koncepcji jest etyczne i społecznie akceptowane zachowanie organizacji biznesowych. CSR może wspierać rozwój zrównoważonych łańcuchów dostaw dzięki narzędziom i metodom ułatwiającym zarządzanie złożonymi relacjami z dostawcami. Zarządzanie kwestiami społecznymi w łańcuchach dostaw staje się coraz ważniejsze. Główny powód to rosnące ryzyko sytuacji niepożądanych. Jednym z możliwych rozwiązań jest wdrożenie kodeksu postępowania lub kodeksu etyki skierowanych do dostawców. Celem artykułu jest pokazanie roli kodeksów jako narzędzi wspierających zarządzanie kwestiami społecznymi i śro- 
dowiskowymi w łańcuchu dostaw. Rozważania teoretyczne są poparte analizą jakościową kodeksów etycznych i kodeksów postępowania publikowanych przez spółki odpowiedzialne społecznie z Polski (w oparciu o IX Ranking Odpowiedzialnych Firm).

Słowa kluczowe: kodeks postępowania, kodeks etyki, odpowiedzialność społeczna w łańcuchu dostaw, analiza jakościowa.

\section{Introduction}

In the twenty-first century the market is extremely demanding. Changes and irrationality of the behaviour of its participants make companies go beyond traditional business values and they begin to create a cooperative relationship based on responsibility and trust. Non-economic values are playing the role in strengthening cooperative links and they can help to minimize the risk of undesirable situations.

The concept of Social Responsibility ${ }^{1}$ helps to create and maintain relationships with different groups of stakeholders [Freeman 1984] including suppliers. It pays special attention to building positive relations in order to achieve mutual benefits and is a way of effective management. To achieve the common goals the cooperation is needed with all stakeholders who have an impact on business objectives and are interested in the effects of business operations. It means the necessity of identification of the needs and expectations of actors that are present in internal and external environment. This can be supported by preparing a stakeholders map that shows existing links between a company and its stakeholders. Equally crucial is the response of organizations addressed to identified stakeholders and their needs. The challenging issue is the creation and multiplication of social and environmental values thanks to this cooperation. ${ }^{2}$

On a typical stakeholders map one can find such key players as: employees, customers, financial institutions, environment and suppliers. Suppliers are becoming more and more important stakeholders nowadays. This is due to the fact that they have a direct impact on the quality of the final product offered on the market and the social and environmental risk that may appear in the connection to their activities. To maintain satisfactory relationships with suppliers both parties need tools and methods which will support the process of shaping appropriate attitudes and enforcing desired behaviour. In practice, we can distinguish a variety of tools to establish and develop relationships with suppliers.

${ }^{1}$ Initially the term Corporate Social Responsibility (CSR) referred mainly to business organizations. The term Responsible Business Conduct is used interchangeably. Currently SR is also used in relations to all such sectors as Social Responsibility of Organizations.

${ }^{2}$ It is worth mentioning the evolution of the concept of creating shared value proposed by M.E. Porter and M.R. Kramer towards the concept of integrated value by Wayne Visser and Chad Kymal [2015]. 
There are tools that help to improve the communication among partners which is very important in the case of a stable flow of information about social and environmental aspects. Informative tools support also the process of monitoring the current situation in supply chain. A good tool used for communication purposes must give the opportunity to get feedback. Dialog sessions and direct meetings seem to be the most sufficient. Educational tools have different meaning. They are especially crucial for good understanding of the context and reasons why suppliers should comply with ethical, environmental and social rules. Learning tools enhance consciousness of noneconomic factors. Programmes, workshops and trainings support the development of culture desired in the supply chain by delivering knowledge and practical solutions. They are needed on each stage of cooperation. In initial phase they are used to present the priorities of social responsibility and at operational stage they are used to transfer the knowledge and skills needed to minimize risks, eliminate problems and develop the whole supply chain. The process of evaluation and assessment is made by using social and environmental audits. Audits are objective tools of getting the information to what extent set criteria and goals are achieved.

Codes of ethics and codes of conduct are tools that socially responsible organizations use to implement norms, principles and rules that they expect from their suppliers. They set the framework for action and determine the minimum scope of social responsibility. What is more they organize the relationship and indicate sensitive areas like e.g. human rights and environmental protection. That is why they should be treated as tools to support the development of the notion of social responsibility and sustainable development in supply chains. Usually the combination of different tools is used. Codes may be the framework of the responsible supply chain management system.

The main goal of the paper is to identify the role of code of ethics and code of conduct as a part of social responsibility of supply chain. It seems that presented tools are important elements of building and maintaining responsible approach among suppliers. Moreover, there is still a research gap between theoretical knowledge about code of conduct and code of ethics and their practical utility.

\section{Codes of ethics and codes of conduct}

Originally ethical codes were created for employees. They "specify the minimum acceptable standards in corporate processes and procedures for them to be successfully implemented, employees need to be both aware of the standards and committed to achieving them." [Haugh, Talwar 2010] The evolution towards codes for external stakeholders is the result of social and ethical challenges that have appeared because of increasing globalization and the search for sources of competitive advantage which is based on cheap production cost and speed of delivery products. The complexity of business processes and related ethical dilemmas caused that some decisions were taken with violation of the moral principles or accepted standards of behaviour. Codes of ethics are a response to the growing problems in the sphere of ethics for a single 
organization and the entire supply chain. It is as "a systematic set of norms and moral rules, which creates a certain system of values, specifying the rules referring to the unit itself, other individuals, groups and entire communities." [Poganowska 2004] Codes of ethics are often part of a broader ethics program like e.g. guide of professional standards, setting up a compliance and ethics cell, the creation of ethical helpline, educational program or their own ethical standards. [Gasparski et al. 2002] According to M. Budgol there are four main reasons for the development of code of ethics in organizations:

- code of ethics is an element of promotion and has to act to strengthen the image of the corporation,

- code of ethics is treated as a tool to avoid the legal consequences associated with unethical behaviour,

- code of ethics as a tool of influence on the behaviour of employees,

- code of ethics as a fashion (without any real value). [Budgol 2007]

The more consciously the code of ethics will be used the greater the benefits it will bring. D. Bąk stresses that the effectiveness of such a tool will be determined by such elements as a form of a document, moral maturity of workers and their participation in the process of code creation, compliance with the provisions of the organizational culture, the adequacy of the code to the prevailing social and cultural conditions, monitoring and evaluation. [Bąk 2010] The code can promote certain principles or identify consequences for non-compliance with the adopted rules of procedure. The code may go beyond the set of moral standards and promote the proper behaviour in certain situations. This kind of code is called code of conduct. It is treated as a guideline of desired behaviour in organization and business relations. It is a helpful tool of improving the ethical culture of organizations with instructions and ways of conduct in morally unclear situations. Both of them can be seen as an element supporting the implementation of corporate social responsibility. Codes of conduct can be divided into five main types: company codes, trade association codes, multi-stakeholder codes, model codes and inter-governmental codes. [Jenkins 2001] If well designed and properly communicated they should play a role of guidelines for ethically oriented company. [Rudnicka 2012]

Development and implementation of the code of conduct relating to risks that may occur in the supply chain is one of the mechanisms of prevention of socially responsible companies. This aspect of CSR management is particularly important for transnational corporations, which in the case of doing business in many different countries are faced with a wide diversity of social and environmental standards and often their complete absence. Code in this case acts as a binding standard [Kenny 2007] of conduct and strengthens the ethical dimension of cooperation between individual links. "Corporations that are initiating social responsibility in global supply chains must develop a strategy which assures that most important suppliers comply with ethical code of conduct". [Cramer 2008] For this reason, they help to promote certain values and provide a framework for drawing the consequences if suppliers go beyond 
the norms and regulations. The mere writing down rules of cooperation may not be enough especially if the supply chain is complex and knowledge of the individual links is limited. In this case a transfer of responsibility from a buyer to suppliers and the transfer of value along the supply chain are expected. The main challenges related to the implementation of codes of ethics include:

- cultural diversity in which each supply chain is present,

- prescriptive nature,

- lack of support from the originators of the code regarding the resources to help in the implementation of the necessary changes,

- lack of commitment of individual links in the formation of the document,

- low motivation, or lack of it to comply with the rules (no visible benefits for links),

- lack of good monitoring and evaluation tools to allow to assess the whole supply chain.

Problems arise already in the primary supplier relationships which just show how complicated organizational and technical process of improving the standards may be putting social responsibility throughout the supply chain. The situation is further complicated by the fact that the business objectives of both sides can vary significantly. Suppliers and byers usually have competing goals and objectives, which may be the source of potential legal and ethical problems. [Bendixen, Abratt 2007] It is also worth underlying that the code of conduct or the code of ethics should initiate changes in supply chain oriented on improving working conditions including health and safety system or wages. This seems to be the most challenging issue. Exemplary research results published by Fair Wear Foundation reveal that there is no clear evidence that the implementation of codes will result in better conditions for workers which suggest that the single document without any additional actions will not work effectively. [Egels-Zanden, Lindholm 2015]

Thus building relationships with suppliers needs good decision making. The code is expected to be treated as part of a broader process of building a climate of trust and cooperation in supply chain.

There are two approaches to the implementation of a code of conduct: topdown approach and bottom-up. The first way may cause additional problems with commitment to the proposed rules among suppliers. It is happening so because of the little influence they have on the terms. A bottom up approach gives a sphere for common decision making and involves suppliers in the process which can be the success factor for the implementation of a code of conduct. [Pedersen, Andersen 2006]

The compliance with the provisions of the codes may be difficult especially in the situation when suppliers have to invest in the relation with buyers and bear some risk of the cooperation. There are some ways that make the agreement between both sides possible:

- the buyer can compensate the supplier for costs associated with code compliance,

- the buyer can reward the supplier for complying with the code, 
- the parties can undertake joint investments in transaction specific assets which will commit both of them to the relationship,

- the parties can achieve strategic CSR goals,

- the buyer can involve the supplier in the planning and implementation of the Codes of conduct, thereby stimulating commitment and goal congruence. [Pedersen, Andersen 2006]

Ethical conduct is an asset for companies providing corporate responsibility towards the stakeholders - all those who make up the organization and with whom it interacts. It is not surprising that more and more companies decide to implement this form of promoting socially responsible activities. From the perspective of socially conscious company a code of conduct or code of ethics is information for customers that the organization has a mature approach to the management of non-economic sphere and aims at building its positive image.

\section{Building socially responsible relationship in supply chains based on the code of ethics and code of conduct. Research results}

The research was desktop studies like type. It was conducted on a group of socially responsible corporations that were ranked in the Ranking Firm Społecznie Odpowiedzialnych published by the Dziennik Gazeta Prawna. Overall 74 firms were surveyed. Most of them belong to the biggest corporations in Poland. The biggest organizations have usually implemented many different tools to create relationships with stakeholders including codes. The research was divided into two parts. The first phase was the analysis of websites of all organizations to check if the codes were available. The internal search and the analysis of links to CSR/sustainability/ corporate governance/business partners were used during the initial phase. Documents available on the global websites of a chosen company were also included to the analysis. The code of ethics addressed mainly to employees or information available on the website as news/announcement were excluded from the analysis.

The second phase aimed at qualitative analysis of the content. The author set a few objectives related to the analysis:

- search for the form of code of ethics and code of conduct,

- how the rules and standards from the documents are transferred within the whole supply chain,

- identification of values promoted in codes,

- recognition of the scope of social responsibility of suppliers,

- assessment of the solutions oriented at the minimization of unethical behaviour among suppliers.

The analysis was based on 20 documents and took place in March 2016. The researched corporations represented a lot of industries: pharmaceutical, energy, banking and finance, food, construction, chemical, FMCG. 
There is a big diversity of names of analysed documents. The documents related to the social responsibility and regarded suppliers were named: code of ethics, code of conduct, code of conduct for suppliers, standards for business partners or ethical rules of conduct. In some cases the code of ethics was a general document for all stakeholders, and did not specify the special requirements for suppliers. In several documents there was information that the code was a part of a wider purchasing policy or responsible sourcing policy. In some cases specific requirements related to the branch were added like the necessity of responsible sourcing and handling with dangerous materials. The content of the codes is very similar despite different volume (from several to more than 15 pages).

The results of the study suggest that the codes addressed to suppliers are rather prescriptive. Corporations expect their suppliers to behave in accordance with international standards of conduct and internal regulations. They insist on complying with the rules and in the cases of nonconformity and a lack of coercive actions they draw the consequences resulting in the termination of cooperation. Suppliers are also accountable for the dispersion of norms and values among their business partners. There is no clear information about the way in which the standard should be implemented and monitored in the whole supply chain. From the perspective of suppliers it is additional duty and very often difficult obligation to fulfil. In practice regulations indicate the need for accountability of suppliers both for their own decisions and their subcontractors. "Supplier should provide at own scope and at own cost the infrastructure and means to minimize the risk of accidents and raising the safety of work" [Code 1] or "Supplier should establish programs to ensure the highest possible level of safety in the area of all operational processes (production, infrastructure and industry, etc.)". [Code 2] "Supplier will establish a management system to ensure compliance with the code, applicable laws, regulations and other requirements or clients, which integrates human rights, labour rights, health and safety, environmental and ethics issues into the business decision making process" [Code 3] or "It is expected that direct suppliers ensure compliance with the principles of this Code of Ethics by their direct suppliers and verify whether these principles are adhered to their supply chains". [Code 4]

It seems that without adequate support from corporations which imposes the obligation to respect the rules by suppliers the implementation of actual provisions is impossible or fraught with high risk of occurrence of undesirable situations. Analysed codes of conduct revealed that most companies set only the general requirements linked to the CSR. Usually they are implemented straight form ILO standards or Global Compact Principles. Codes of conduct are the framework for ethical and socially responsible behaviour and should be treated as guidelines for developing strategic approach to social and environmental challenges. They do not contain detailed information about possible actions or objectives to achieve, which may be an additional problem especially for these organizations that are not socially conscious. Documents did not contain business specific risks, which may have decreased their credibility too. 
The following table shows the main issues that define the responsibilities of suppliers based on the conducted analysis.

Table 1. The main areas of Social Responsibility of Suppliers

\begin{tabular}{|l|}
\multicolumn{1}{|c|}{ Social aspects } \\
\hline - human rights \\
- decent work \\
- child labour \\
- cair wages conditions \\
- non discrimination \\
- forced labour \\
- freedom of association \\
\hline \multicolumn{1}{c|}{ Safe and healthy working conditions } \\
\hline - accident prevention \\
- personal protection \\
\hline compliance with rules and requirements \\
\hline - pollution prevention \\
- waste management \\
- environmental friendly technologies \\
\hline \\
\hline - compliance with the rules of fair competition \\
- a ban on bribery \\
- a ban on corruption
\end{tabular}

Source: own elaboration.

Companies guarantee themselves the right to verify the degree of compliance with the requirements based on self-evaluation, audits, regular visits to the suppliers' factories and talks with employees. ${ }^{3}$

With few exceptions, the analysed documents did not indicate the main values of the company. The lack of communication of such an important element of organizational culture may be the next barrier of successful implementation of social standards. It limits the possibilities of getting to know the main reasons and justification for suppliers why they should follow some rules. All issues seem to be very sensitive for business operations and sometimes they may not be included in the standards of a process of decision making. It is why the broader presentation of motives and expected results may be crucial. The research showed that codes of conduct and codes of ethics did not provide the readers with instructions and guidelines of preventive actions. There were no clear benefits identified either. The only issue which was

${ }^{3}$ Based on the analysed documents. 
discussed were sanctions. This kind of approach may be demotivating. Additional benefits for suppliers, better contract terms or longer time contracts may be considered as a source of motivation for long term win-win relationship.

\section{Conclusions}

The codes that regulate the social and environmental issues of supply chain are usually implemented by corporations that seek a way how to demonstrate their social responsibility. The challenge is to transfer the rules of conduct into business practice. The code of conduct or the code of ethics themselves do not guarantee that the supplier will behave in an expected way. This is the reason way those kinds of documents should be rather an element of broader ethical infrastructure or management system than the only mechanism of prevention. The analysis shows that the codes of ethics and conduct addressed to suppliers have mostly the prescriptive character. Business partners are expected to behave in accordance with a set of standards but at the same time they are not provided with the tools to support the implementation of the provisions contained in the documents. One of possible solutions is the integration of codes with the process of cooperation and monitoring of processes in a supply chain. Above all the education and understanding of social and environmental risks is highly required. Good practices and cooperation with partners from the whole life cycle of the product on operational level might be a primary need. This solution seems to be particularly useful for suppliers who do not take into their consideration social responsibility of business operations. Their awareness in this area may be insufficient for the proper planning and monitoring of links and processes which they are responsible for. Documents should be the first step for the identification of the most important issues of supply chains and a starting point for further development. In this sense, to some extent, they seem to be proper tools that support the implementation of principles of social responsibility. The huge limitation of the role of codes is their use in relation to the first row suppliers only. It is highly possible that unclear guidelines for the use of such documents throughout the supply chain and the lack of a coordinated strategy in this area will not lead to the minimization of the risks for the entire supply chain. It is especially crucial in long and complex chains with initial links in developing countries where the social and environmental standards are very often poor. The greater the likelihood of violations of certain norms and standards the more important the role of safeguards against such events. The shift from records of codes to concrete and specific actions remains the main challenge for companies.

The limitation of the study was the scale of research related to the number of available documents. The analysis should be rather treated as introductory research of social responsible strategies in a supply chain. There is still lack of transparent information about a supply chain on webpages. The results presented in the paper indicate the main points that should be taken into consideration when designing and 
implementing codes. The next step of research may be the analysis of the voice of suppliers to identify their real needs and expectations of building common goals and plans for responsible supply chains.

\section{References}

Bąk D., 2010, Instrumenty kreowania standardów etycznych w organizacji. Projektowanie, ocena, Zarządzanie Zasobami Ludzkimi, nr 2, pp. 11-27.

Bendixen M., Abratt R., 2007, Corporate identity, ethics and reputation in supplier-buyer relationships, Journal of Business Ethics, Vol. 76, Iss. 1, pp. 69-82.

Budgol M., 2007, Gry i zachowania nieetyczne w organizacji, Difin, Warszawa.

Code 1: Kodeks postępowania etycznego Grupy Raben.

Code 2: Kodeks postępowania dla dostawców Sanofi.

Code 3: Kodeks postępowania dla dostawców Samsung.

Code 4: Kodeks etyki dostawców Górażdże.

Cramer J.M., 2008, Organising Corporate Social Responsibility in international product chains, Journal of Cleaner Production, Vol. 16, pp. 395-400.

Egels-Zanden N., Lindholm H., 2015, Do codes of conduct improve worker rights in supply chains? A study of Fair Wear Foundation, Journal of Cleaner Production, No. 107, pp. 31-40.

Freeman R.E., 1984, Strategic Management: A Stakeholder Approach, Pitman, Boston.

Gasparski W., Lewicka-Strzałecka A., Rok B., Szulczewski G., 2002, Etyka biznesu w zastosowaniach praktycznych, inicjatywy, programy, kodeksy, CEBI, IFiS PAN\&WSPiZ, Biuro Stałego Koordynatora ONZ w Polsce, Warszawa.

Haugh H.M., Talwar A., 2010, How do corporations embed sustainability across the organization?, Academy of Management Learning \& Education, Vol. 9, no. 3, pp. 384-396.

Jenkins R., 2001, Corporate codes of conduct: Self-regulation in a global economy, United Nations Research Institute for Social Development, Technology, Business and Society Programme, Paper Number 2.

Kenny K.E., 2007, Code or contract: Whether Wal-Mart's code of conduct creates a contractual obligation between Wal-Mart and the employees of its foreign suppliers, Northwestern Journal of International Law \& Business, Volume 27, Issue 2.

Pedersen E.R., Andersen M., 2006, Safeguarding Corporate Social Responsibility (CSR) in global supply chains: How codes of conduct are managed in buyer-supplier relationships, Journal of Public Affairs, August-November.

Poganowska B., 2004, Elementy etyki gospodarki rynkowej, PWE, Warszawa.

Rudnicka A., 2012, CSR - doskonalenie relacji społecznych w firmie, Wolters Kluver, Warszawa.

Visser W., Kymal Ch., 2015, Integrated Value Creation (IVC): Beyond Corporate Social Responsibility (CSR) and Creating Shared Value (CSV), Journal of International Business Ethics Vol. 8, No 1, pp. 29-43. 